\title{
Lampreys of the Iberian Peninsula: distribution, population status and conservation
}

\author{
Catarina S. Mateus ${ }^{1,2,3, *}$, Rolando Rodríguez-Muñoz ${ }^{4,5}$, Bernardo R. Quintella ${ }^{1,6}$, \\ M. Judite Alves ${ }^{3}$, Pedro R. Almeida ${ }^{1,2}$ \\ ${ }^{1}$ Centro de Oceanografia, Faculdade de Ciências da Universidade de Lisboa, Campo Grande, 1749-016 Lisbon, Portugal \\ ${ }^{2}$ Departamento de Biologia, Escola de Ciências e Tecnologia, Universidade de Évora, Largo dos Colegiais, 7000 Évora, \\ Portugal
}

${ }^{3}$ Museu Nacional de História Naturale da Ciência \& Centro de Biologia Ambiental, Universidade de Lisboa, 1250-102 Lisbon, Portugal

${ }^{4}$ Centre for Ecology \& Conservation, School of Biosciences, University of Exeter, Cornwall Campus, Penryn, TR10 9EZ, UK

${ }^{5}$ Área de Zoología, Facultad de Biología, Universidad de Oviedo, Calle Catedrático Rodrígo Uría s/n, 33006 Oviedo, Spain

${ }^{6}$ Departamento de Biologia Animal, Faculdade de Ciências da Universidade de Lisboa, Campo Grande, 1749-016 Lisbon, Portugal

\begin{abstract}
The 3 lamprey species, sea lamprey Petromyzon marinus L., European river lamprey Lampetra fluviatilis L. and European brook lamprey L. planeri Bloch, that inhabit the Iberian Peninsula are of conservation concern. They are considered either Vulnerable, Critically Endangered, and even Extinct in different regions of this area mainly due to habitat loss and population fragmentation. Although several other factors contribute to the decline of lamprey populations in Iberian rivers, obstacles to migration (dams and weirs) are probably the most widespread and significant, causing an estimated $80 \%$ loss of accessible habitat in most river basins. We analysed historical records from all main Iberian rivers before the construction of impassable dams became widespread, and found that lampreys were consistently present in the upper reaches. The unblocking of the lower stretches of major river basins and the restoration of former spawning sites and larval habitats should be considered as priority measures for the conservation of these species. Identification of Special Areas of Conservation to be included in the Natura 2000 European network can also be very relevant for lamprey conservation.
\end{abstract}

KEY WORDS: Petromyzon marinus $\cdot$ Lampetra fluviatilis $\cdot$ Lampetra planeri $\cdot$ Historical distribution $\cdot$ Habitat loss $\cdot$ Conservation options

\section{INTRODUCTION}

Living lampreys are represented by 3 families with antitropical distributions. Two families are endemic to the southern hemisphere and the third to the northern hemisphere (Hubbs \& Potter 1971, Gill et al. 2003). Northern lampreys belong to the family Petromyzontidae, which contains 38 of the 42 current species (Lang et al. 2009). Three of those species occur in the Iberian Peninsula (i.e. sea lamprey Petromyzon mari- nus L., 1758, European river lamprey Lampetra fluviatilis L., 1758 and European brook lamprey L. planeri Bloch, 1784). The first 2 are anadromous and parasitic, and the other is freshwater resident and non-parasitic. The European river and brook lampreys are considered 'paired species', i.e. they are closely related and morphologically very similar but have different modes of adult life (Zanandrea 1959).

The Iberian Peninsula was one of the most important refugia in the European subcontinent during the 
Pleistocene glaciations, acting intermittently as a refugium and a source for postglacial expansion. Many species display a strong population substructure within Iberia and are actually composed of isolated populations in distinct Iberian subrefugia as a consequence of extended periods of isolation throughout the ice ages (Gómez \& Lunt 2006). The recognition of refugia and subrefugia has implications for conservation genetics, highlighting the areas where conservation efforts should be concentrated. Overall, the southern regions are of particular interest because they support most of the current genetic variation of taxa not adapted to very cold environments. Thus, overall long-term conservation may benefit from the preservation of genetic diversity in these areas (Taberlet et al. 1998).

All lampreys of the Iberian Peninsula are of conservation concern. The sea lamprey is the only one that has economic value both in Portugal and Spain and is subjected to intensive exploitation. However, it is considered the least threatened of the 3 lampreys. In Portugal, Lampetra fluviatilis and L. planeri are currently included in the Critically Endangered category of the Portuguese Red List of Threatened Vertebrates, and Petromyzon marinus is classified as Vulnerable (Cabral et al. 2005). In Spain, L. fluviatilis is considered Regionally Extinct, L. planeri is Critically Endangered, and P. marinus is Vulnerable (Doadrio 2001). Globally and in Europe, the 3 species are considered of Least Concern according to the International Union for Conservation of Nature (IUCN) Red List of Threatened Species (Freyhof \& Kottelat 2008a,b,c), and the European Red List of Freshwater Fishes (Freyhof \& Brooks 2011), respectively. Yet $P$. marinus is considered threatened in the European countries holding the main populations (i.e. France, Spain and Portugal). Table 1 lists the current IUCN categories for each species in the countries of their natural range for which this information exists.

In this paper, we analyse the distribution, conservation status and population trends of Iberian lampreys. In particular, we compare historical and recent records of lampreys in Iberian rivers, estimate habitat loss, discuss the factors that contributed most to their decline and recommend conservation measures that may contribute to their recovery.

\section{SYSTEMATICS}

Lampreys (Superclass Petromyzontomorphi) together with the exclusively marine hagfishes (Superclass Myxinomorphi) represent the most primitive extant vertebrates (Renaud 1997). Living lampreys are represented by 3 distinct monophyletic groups, currently recognised as distinct families. Two of these are endemic to the southern hemisphere (Geotriidae and Mordaciidae), and the third is restricted to the northern hemisphere (Petromyzontidae; Hubbs \& Potter 1971, Gill et al. 2003).

The term 'paired species' is applied to pairs of closely related and morphologically similar lampreys of which one is non-parasitic (brook lamprey) and the other a parasitic species (Zanandrea 1959). Vladykov \& Kott (1979) introduced the more general term 'satellite species' to apply to those cases in which more than 1 brook lamprey species has apparently derived from a single parasitic species. There has been much controversy about the taxonomic status of paired lamprey species. Some earlier authors suggested that parasitic and non-parasitic forms are not fully differentiated species (e.g. Eneqvist 1937, McPhail \& Lindsey 1970), and more recently, genetic studies using distinct molecular markers (especially mitochondrial DNA) failed to find genetic differences between lamprey species pairs (e.g. Docker et al. 1999, Espanhol et al. 2007, Blank et al. 2008, Hubert et al. 2008).

Are the ecological differences between species pairs associated with distinct gene pools, or do environmental factors trigger a divergent adult phase? There is likely not a single answer for all lamprey species pairs (Docker 2009). Schreiber \& Engelhorn (1998) studied allozyme markers of the paired species Lampetra fluviatilis and L. planeri and suggested that there was gene flow between these species where they occurred in sympatry and that the 2 are therefore not distinct species. Also, Espanhol et al. (2007) and more recently Mateus et al. (2011a) analysed the phylogeography of Iberian and European populations of the species pair L. fluviatilis and L. planeri using the cytochrome $b$ and ATPase (subunits 6 and 8) genes, and in both studies, the clades recovered were not species specific. Analysis of more variable genetic markers, like microsatellite loci, is needed to help understand whether this species pair is composed of 2 recently diverged species or of 2 forms of the same species. Microsatellite loci are highly polymorphic and have high mutation rates, making them especially useful for the study of fine-scale population structure as they are capable of detecting differences among closely related populations or recently diverged species (O'Connell \& Wright 1997).

Mateus et al. (2011a) identified highly divergent allopatric lineages in the Iberian Peninsula and suggested the existence of a complex of incipient or 
Table 1. Petromyzon marinus and Lampetra spp. 2001 International Union for Conservation of Nature (IUCN) Red List categories for countries where information exists across their natural range. In Italy, P. marinus and L. fluviatilis are often classified as Regionally Extinct, but these species still reproduce at least in the River Magra (Bianco \& Delmastro 2011). In Slovenia, $P$. marinus is present in the Adriatic river basin (Povž 2002). In Lithuania, L. fluviatilis and L. planeri are common, not being included in the Red data book (T. Virbickas \& R. Repecka pers. comm.). RE: Regionally Extinct; CR: Critically Endangered; EN: Endangered; VU: Vulnerable; n/t: not threatened; LC: Least Concern; DD: Data Deficient; NE: Not Evaluated. Other categories are R: Rare; NT: Near Threatened; LR: Lower Risk; NA: not applicable; X: species occurrence not confirmed $;-$ : no data available/not included in the Red data book

\begin{tabular}{|c|c|c|c|c|c|c|}
\hline \multirow[t]{2}{*}{ Country } & \multicolumn{2}{|c|}{ P. marinus -} & \multicolumn{2}{|c|}{$\longrightarrow$ L. fluviatilis $\longrightarrow$} & \multicolumn{2}{|c|}{$\longrightarrow$ L. planeri $\longrightarrow$} \\
\hline & IUCN & Source & IUCN & Source & IUCN & Source \\
\hline Russia & EN & $\begin{array}{l}\text { Russian Academy of Sciences } \\
\text { (2001) }\end{array}$ & - & - & - & - \\
\hline Finland & $\mathrm{NA}^{\mathrm{a}}$ & Rassi et al. (2010) & NT & $\begin{array}{l}\text { Rassi et al. (2010), } \\
\text { Urho \& Lehtonen (2008) }\end{array}$ & $\mathrm{LC}$ & Kaukoranta et al. (2000) \\
\hline Norway & $\mathrm{LC}^{\mathrm{b}}$ & Kålås et al. (2010) & $\mathrm{LC}^{\mathrm{b}}$ & Kålås et al. (2010) & $\mathrm{LC}^{\mathrm{b}}$ & Kålås et al. (2010) \\
\hline Sweden & NT & Gärdenfors (2010) & $\mathrm{LC}$ & Gärdenfors (2010) & $\mathrm{LC}$ & Gärdenfors (2010) \\
\hline Estonia & $\mathrm{NE}^{\mathrm{c}}$ & Lilleleht et al. (2008) & $\mathrm{LC}$ & Lilleleht et al. (2008) & DD & Lilleleht et al. (2008) \\
\hline Ireland & VU & Maitland (2004) & LR & Maitland (2004) & LR & Maitland (2004) \\
\hline Great Britain & VU & Maitland (2000) & VU & Maitland (2000) & VU & Maitland (2000) \\
\hline Denmark & VU & Carl et al. (2004) & $\mathrm{DD}^{\mathrm{d}}$ & Carl et al. (2004) & $\mathrm{LC}$ & Carl et al. (2004) \\
\hline Lithuania & $\mathrm{EN}^{\mathrm{e}}$ & Rašomavičius (2007) & - & - & - & - \\
\hline Poland & EN & Głowaciński et al. (2002) & VU & Głowaciński et al. (2002) & VU & Witkowski et al. (2003) \\
\hline Belgium - Flanders & $\mathrm{RE}$ & Kestemont (2010) & $\mathrm{R}$ & Kestemont (2010) & VU & Kestemont (2010) \\
\hline Belgium - Wallonia & $\mathrm{RE}^{\mathrm{f}}$ & $\begin{array}{l}\text { Philippart (2007), } \\
\text { Kestemont (2010) }\end{array}$ & $R E^{\mathrm{f}}$ & $\begin{array}{l}\text { Philippart (2007), } \\
\text { Kestemont (2010) }\end{array}$ & VU & $\begin{array}{l}\text { Philippart (2007), } \\
\text { Kestemont (2010) }\end{array}$ \\
\hline Germany & $\mathrm{n} / \mathrm{t}$ & Freyhof (2002) & $\mathrm{n} / \mathrm{t}$ & Freyhof (2002) & $\mathrm{n} / \mathrm{t}$ & Freyhof (2002) \\
\hline Czech Republic & $\mathrm{RE}$ & Lusk et al. (2004) & $\mathrm{RE}$ & Lusk et al. (2004) & EN & $\begin{array}{l}\text { Witkowski et al. (2003), } \\
\text { Lusk et al. (2004) }\end{array}$ \\
\hline Ukraine & $\mathrm{X}$ & $\mathrm{X}$ & - & - & $\mathrm{LC}$ & Witkowski et al. (2003) \\
\hline Slovakia & - & - & $\mathrm{X}$ & $\mathrm{X}$ & $\mathrm{CR}$ & Witkowski et al. (2003) \\
\hline Switzerland & - & - & $\mathrm{RE}$ & Kirchhofer et al. (2007) & EN & Kirchhofer et al. (2007) \\
\hline France & NT & IUCN France et al. (2010) & VU & IUCN France et al. (2010) & $\mathrm{LC}$ & IUCN France et al. (2010) \\
\hline Slovenia & $\mathrm{EN}^{g}$ & Povž (2011) & $\mathrm{X}$ & $\mathrm{X}$ & - & - \\
\hline Croatia & $\mathrm{DD}$ & Mrakovčič et al. (2007) & $\mathrm{X}$ & $\mathrm{X}$ & NT & Mrakovčič et al. (2007) \\
\hline Italy & - & - & - & - & NT & Bianco et al. (2011) \\
\hline Spain & $V^{h}$ & Doadrio (2001) & $\mathrm{RE}$ & Doadrio (2001) & $\mathrm{CR}^{\mathrm{i}}$ & Doadrio (2001) \\
\hline Portugal & VU & Cabral et al. (2005) & $\mathrm{CR}$ & Cabral et al. (2005) & $\mathrm{CR}$ & Cabral et al. (2005) \\
\hline \multicolumn{7}{|c|}{ 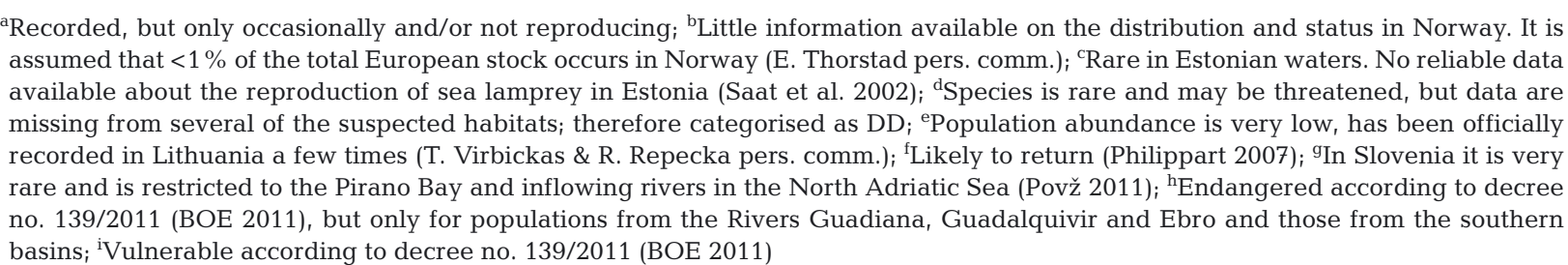 } \\
\hline
\end{tabular}

cryptic species in this region. These authors identified a number of Iberian populations that merit separate management and have high priority for conservation as Evolutionary Significant Units (ESUs) or Management Units (MUs). Four ESUs were defined for Lampetra planeri, 3 exclusive to the Iberian Peninsula (Sado basin, River Nabão and Esmoriz/ Vouga basins) and another that is distributed across Europe. For L. fluviatilis, a unit including not only the threatened Iberian population but also populations from across Europe was suggested (Mateus et al. 2011a). Both Espanhol et al. (2007) and Mateus et al. (2011a) found that genetic diversity is considerably higher in Iberian populations compared to European populations, which reflects the persistence and independent evolution in refugia and subrefugia during the ice ages.

For the sea lamprey, analysis of the mitochondrial control region has been used to compare populations from the Iberian Peninsula with populations from North America (Rodríguez-Muñoz et al. 2004). Iberian samples showed an almost identical frequency of the observed haplotypes, but none of these haplotypes was found among North American populations, suggesting that sea lamprey populations living on each side of the Atlantic have a long history of repro- 
ductive isolation. The authors suggested that the low number of haplotypes observed in sea lamprey from Spanish rivers is evidence for bottlenecking and suggest that analysis of nuclear DNA microsatellite variation is required (Rodríguez-Muñoz et al. 2004). Bryan et al. (2005) used microsatellite loci to investigate the spatial structure, invasion dynamics and origins of sea lamprey populations in the Great Lakes and anadromous populations in North America. The authors included an anadromous population from the River Mondego (central Portugal) in the analysis and concluded that this population had the lowest average number of alleles per locus of any sea lamprey population examined, showing evidence of a genetic bottleneck probably due to a large reduction in population size, and reflecting the vulnerable state of sea lamprey populations in Europe (Bryan et al. 2005). Population bottlenecks reduce genetic variation and, consequently, the population's capacity to face environmental changes. These results support the assumption that European and North American sea lamprey populations are reproductively isolated and should be managed independently.

\section{DISTRIBUTION}

\section{Present distribution}

The genera Petromyzon (monospecific) and Lampetra are represented both in Europe and North America, and within the genus Lampetra, 2 species, the European river and brook lampreys, are endemic to Europe (Hardisty 1986a).

Petromyzon marinus is distributed on both sides of the North Atlantic. In North America, it occurs on the east coast from Labrador (Canada) in the north $\left(53^{\circ} \mathrm{N}\right)$ to Florida (USA) in the south $\left(30^{\circ} \mathrm{N}\right)$. In
Europe, it can be found from the Barents Sea (Kola Peninsula, $\left.70^{\circ} \mathrm{N}\right)$ in the north to the Iberian Peninsula $\left(38^{\circ} \mathrm{N}\right)$ in the southwest and Adriatic Sea $\left(40^{\circ} \mathrm{N}\right)$ in the southeast (Hardisty 1986b). It has also been documented in the Aegean Sea (Economidis et al. 1999) and the Levantine Sea (eastern Mediterranean; Cevik et al. 2010). Occasionally, it occurs off Iceland, Greenland and in the North and Baltic Seas (Hardisty 1986b). It has occasionally been found at lower latitudes in northern Africa (Boutellier 1918, Dollfus 1955). Several landlocked populations inhabit the North American Great Lakes, but none has been reported for Europe (Kottelat \& Freyhof 2007). Fig. 1A shows the present distribution of $P$. marinus on the Iberian Peninsula. In Spain, it occurs in most rivers flowing into the Cantabrian Sea and the Atlantic Ocean, as well as some of the Mediterranean (Fig. 1A). Along the Cantabric coast, it is present in nearly all river basins located west of the River Deva. These basins include the Mera, Ouro, Masma and Eo in Galicia (Cobo et al. 2010), and the Navia, Nalón, Sella and Deva in Asturias (Rodríguez-Muñoz 1992). It occurs at the lower reaches of the River Bidasoa (Navarra), in the Bay of Biscay and at the eastern end of the Cantabrian Sea (Doadrio 2001). Along the Atlantic coast, it can be found in the basins of the Rivers Mandeo, Anllóns, Tambre, Ulla, Umia and Lérez in Galicia (Cobo et al. 2010), and in the Guadiana, Guadalquivir estuary, Guadalete and Barbate in Andalusia. In the Mediterranean, it is found in the Guadiaro and Ebro (Doadrio 2001; Fig. 1A). In Portugal, it occurs in all major river basins (Minho, Lima, Cávado, Douro, Vouga, Mondego, Tagus and Guadiana, Fig. 1A), being more abundant in the central and northern regions of the country (Almeida et al. 2008).

Lampetra fluviatilis is restricted to European watersheds, where its range extends from southern
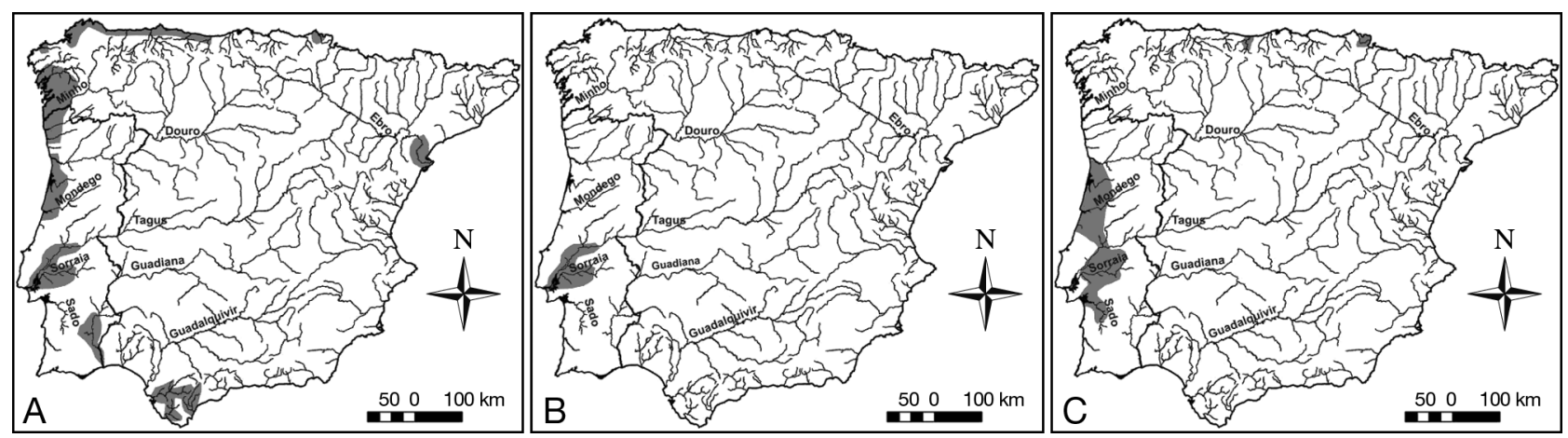

Fig. 1. Petromyzon marinus and Lampetra spp. Geographic distribution (gray shading) of (A) P. marinus, (B) L. fluviatilis and (C) L. planeri in the Iberian Peninsula 
Norway (around Bergen), along the Baltic and North Sea coasts, the Atlantic waters of the British Isles, France and the Iberian Peninsula (River Tagus), to the western Mediterranean (along French and western Italian coasts; Hardisty 1986c). It has also been reported for Turkey (Erguven 1989). In contrast to the rare sea lamprey, the river lamprey is generally a common and widely distributed member of the ichthyofauna of the Baltic Sea (Thiel et al. 2009). There are occasional records in Adriatic and Ionian seas. Landlocked populations are known from Lakes
Ladoga and Onega and the Volga basin (Russia), Loch Lomond (Scotland), some lakes in Finland and possibly Lough Neagh (Northern Ireland; Kottelat \& Freyhof 2007). On the Iberian Peninsula (Fig. 1B), the river lamprey lives as a single isolated population in the Portuguese part of the Tagus river basin (Almaça \& Collares-Pereira 1988), which is extremely reduced (Cabral et al. 2005). Its distribution is limited by the Belver dam in the Tagus $(150 \mathrm{~km}$ from the river mouth), Castelo de Bode dam in the River Zêzere (12 $\mathrm{km}$ from the confluence with the Tagus), Mon-

Table 2. First obstacles to the migration of Petromyzon marinus and Lampetra fluviatilis in the main Iberian rivers and some main tributaries where they occur, with reference to their construction year, distance from the river mouth and, for the main basins with historical records, habitat loss quantification in the main stream. When the obstacle is located in a tributary, the main stream is given in parentheses. Numbers correspond to obstacles shown in Fig. 2. Present available habitat and habitat loss were both measured along the main stream, with no information on tributaries. Data sources: Assis (1990), GranadoLorencio (1991, 1996), Rodríguez-Muñoz (1992), Almeida et al. (2000, 2002), Santos et al. (2002), Quintella (2006), Andrade et al. (2007), Cobo et al. (2010), unpubl. data. NA: not applicable; -: lack of historical data

\begin{tabular}{|c|c|c|c|c|c|c|}
\hline Country & River & Obstacle & No. & $\begin{array}{c}\text { Construction } \\
\text { year }\end{array}$ & $\begin{array}{l}\text { Present available } \\
\text { habitat }(\mathrm{km})\end{array}$ & $\begin{array}{l}\text { Habitat loss } \\
(\mathrm{km})\end{array}$ \\
\hline \multicolumn{7}{|l|}{ Spain } \\
\hline \multirow[t]{5}{*}{ Asturias } & Cares (Deva) & Niserias weir & 1 & Unknown & 24 & - \\
\hline & Sella & Caño weir & 2 & Unknown & 35 & - \\
\hline & Nalón & Valduno dam & 3 & 2000 & 29 & - \\
\hline & Narcea (Nalón) & Calabazos dam & 4 & 1966 & $33^{\mathrm{a}}$ & - \\
\hline & Navia & Arbón dam & 5 & 1967 & 15 & - \\
\hline \multirow[t]{11}{*}{ Galicia } & Eo & Pé de Vinã weir & 6 & 1993 & 32 & - \\
\hline & Masma & Celeiro weir & 7 & Unknown & 7 & - \\
\hline & Ouro & Piscifactoría do Ouro weir & 8 & Unknown & 9 & - \\
\hline & Mera & Natural obstacle & 9 & NA & 11 & - \\
\hline & Mandeo & Maquias de Chelo weir & 10 & Unknown & 12 & - \\
\hline & Anllóns & C.H. Anllóns dam & 11 & Unknown & 13 & - \\
\hline & Tambre & Barrié de La Maza dam & 12 & 1958 & 16 & - \\
\hline & Ulla & Weir & 13 & Unknown & 60 & - \\
\hline & Umia & Segade waterfall & 14 & NA & 26 & - \\
\hline & Lérez & Bora weir ${ }^{\mathrm{b}}$ & 15 & Unknown & 7 & - \\
\hline & Minho $^{\mathrm{c}}$ & Frieira dam & 16 & 1970 & 80 & $174(69 \%)$ \\
\hline \multirow[t]{4}{*}{ Andalusia } & Chanza (Guadiana) & Chanza dam & 27 & 1989 & $0.5^{\mathrm{d}}$ & - \\
\hline & Guadalquivir & Alcalá del Río dam & 28 & 1931 & 104 & $290(74 \%)$ \\
\hline & Guadalete & Arcos dam & 29 & 1965 & 84 & - \\
\hline & Barbate & Barbate dam & 30 & 1992 & 50 & - \\
\hline Tarragona & Ebro & Flix dam & 31 & 1948 & 116 & $564(83 \%)$ \\
\hline \multirow{10}{*}{ Portugal } & Lima & Touvedo dam & 17 & 1993 & 48 & - \\
\hline & Cávado & Penide dam & 18 & 1951 & 27 & - \\
\hline & Douro $^{\mathrm{C}}$ & Crestuma-Lever dam & 19 & 1985 & 20 & $496(96 \%)$ \\
\hline & Vouga & Grela dam & 20 & 1993 & 53 & - \\
\hline & Mondego & Açude-Ponte dam & 21 & 1981 & 35 & - \\
\hline & Zêzere (Tagus) & Castelo de Bode dam & 22 & 1951 & $12^{\mathrm{e}}$ & - \\
\hline & Tagus $^{\mathrm{C}}$ & Belver dam & 23 & 1952 & 150 & $483(76 \%)$ \\
\hline & Sôr (Tagus) & Montargil dam & 24 & 1958 & $91^{\mathrm{e}}$ & - \\
\hline & Raia (Tagus) & Gameiro weir & 25 & 1960 & $20^{\mathrm{f}}$ & - \\
\hline & Guadiana $^{\mathrm{c}}$ & Pedrogão dam ${ }^{g}$ & 26 & 2005 & 132 & $516(80 \%)$ \\
\hline \multicolumn{7}{|c|}{ 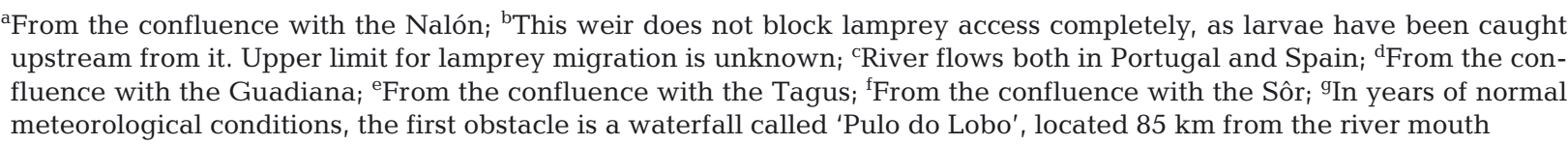 } \\
\hline
\end{tabular}




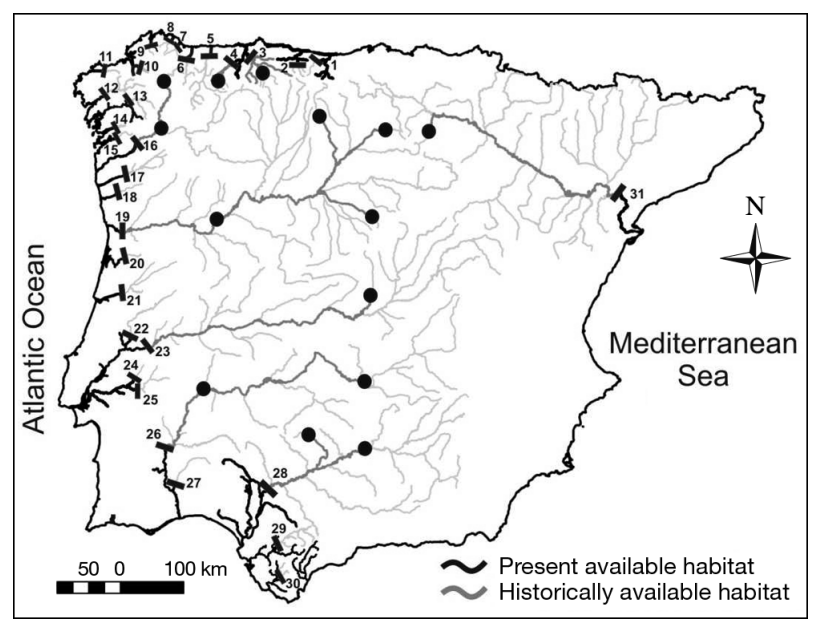

Fig. 2. Iberian Peninsula, showing the first insurmountable obstacles (black bars, numbered as in Table 2) to the migration of Petromyzon marinus and Lampetra fluviatilis, present available habitat (in black) and historically available habitat (dark grey) in the main river basins, and location of historical lamprey records (black dots). Historically available habitat was considered as the river stretch between the first insurmountable obstacle and the historical record located more upstream in the main course. When records were located in tributaries, the upper limit was considered their confluence with the main course. Only rivers with lamprey records are included. Data sources are given in the text ('Distribution' section)

targil dam in the River Sôr $(91 \mathrm{~km}$ from the confluence with the Tagus) and Gameiro weir in the River Raia $(20 \mathrm{~km}$ from the confluence with the Sôr; Table 2, Fig. 2).

The distributional range of Lampetra planeri coincides for the most part with that of L. fluviatilis, although the former penetrates farther inland in central and northern Europe (Hardisty 1986d). L. planeri occurs in rivers draining into the North Sea north to Scotland and around Stavanger (Norway), in the Baltic Sea basin and in the Atlantic Ocean basin as far south as Portugal, in the Mediterranean basin in France and in western Italy. It occurs in the upper and middle parts of the Volga basin and in the Danube basin. On the Iberian Peninsula, the brook lamprey is more widely distributed than its parasitic counterpart (Fig. 1C). It is widespread in the west Iberian basins, with confirmed presence in the Douro, Esmoriz, Vouga, Mondego, Lis, Ribeiras do Oeste, Tagus and Sado river basins (Espanhol et al. 2007, Mateus et al. 2011a). In Spain, a population inhabits the River Olabidea (Navarra) close to the Pyrenees, a tributary of the River Adour in France, which flows into the Cantabrian Sea at the Bay of Biscay (Doadrio 2001). The genus Lampetra was recently reported during a sampling survey in the River
Deva in the central Cantabrian Sea, northern Spain (Mateus et al. 2011b); this population was later assigned to L. planeri (Perea et al. 2011).

On the Iberian Peninsula, the 3 species live in sympatry in a single basin, the River Tagus, and within this basin, the co-occurrence of all 3 species has only been confirmed in the River Sorraia, the main tributary of the Tagus basin (C. S. Mateus et al. pers. obs.). The sea and brook lampreys co-occur in other rivers, such as the Vouga and Mondego in Portugal and the Deva in Spain.

\section{Historical distribution}

Historical data on lamprey distribution in the Iberian Peninsula are very scarce. First records were published in the late 19th and early 20th centuries (Steindachner 1866, Gibert 1912), but some data on lamprey distribution are also available from references on geography and history, with no details on species identity (e.g. Miñano 1827a, Escolar 1865). Because lampreys are rarely confused with other fish, these references are probably quite reliable in terms of how widespread lampreys were in the recent past. Before the building of insurmountable dams, lampreys were present at the headwaters and tributaries of all major Iberian basins (Miñano 1827a,b, Escolar 1865, Baldaque da Silva 1891, Granado-Lorencio 1991, 1996, Abel 1998, Fernández Pasquier 1999, Torrente 1999, Doadrio 2001, PérezBote 2002, Elvira 2004, Pérez-Bote et al. 2005, Frutos 2011; Fig. 2). After the building of most of the dams during the second half of the 20th century (Santo 2005, Cea Azañedo \& Sánchez Cabezas 2007), upstream migration became blocked at the lower stretches of all major rivers, interrupting the movement of lampreys along most of the main stem and principal tributaries, with an estimated $80 \%$ loss of accessible habitat (Table 2, Fig. 2). In the Guadalquivir river basin, some of the most important migratory species (i.e. sea lamprey, sturgeon Acipenser sturio L. and shad Alosa alosa L.) seem to have disappeared completely (Granado-Lorencio 1991).

\section{HABITAT REQUIREMENTS}

Lampreys distribute via 2 contrasting behaviours: upstream spawning migration of adults and downstream drift of ammocoetes. Through these opposing movements, adult lampreys find suitable spawning conditions, and ammocoetes locate the silted bottoms 
of the middle and lower courses, where conditions are favourable for their feeding and burrowing activities (Hardisty \& Potter 1971).

\section{Ammocoetes}

Studies of the influence of environmental variables on the distribution and abundance of larval lampreys have primarily focused on small-scale analysis of general preferences and requirements (e.g. Malmqvist 1980, Almeida \& Quintella 2002, Sugiyama \& Goto 2002). Recently, the need to develop studies that allow the evaluation and prediction of lamprey occurrence/ abundance at multiple spatial scales has been emphasised. For example, Almeida et al. (2011a) found that the presence of Lampetra ammocoetes in Portuguese basins is strongly associated with abiotic macro-scale predictors related to lithology, altitude, water availability and temperature. This large-scale approach was particularly important, as the information gathered could be used as a tool to prioritise rivers for conservation of these species.

Ammocoetes select soft substrates where the current is slow but relatively constant, in mainstream areas protected from major environmental fluctuations and with a plentiful food supply in the form of microalgae and particulate organic matter. Such conditions are commonly found in eddies, backwaters, at bends or behind obstacles, where organic material tends to accumulate. These areas, which are often partially shaded by trees, are favourable for the growth of diatoms, the preferred food item (Hardisty \& Potter 1971, Hardisty 1979). Ammocoete colonisation is most dependent on stream gradients which dictate overall current velocity, the type of substrate particles that are deposited and the accumulation of organic debris (Hardisty \& Potter 1971). The influence of the sediment particle size and current velocity on ammocoete distribution was recognised early on by many authors (e.g. Hardisty 1944, Baxter 1957, Malmqvist 1980, Morman et al. 1980, Potter et al. 1986, Almeida \& Quintella 2002). Other variables such as the organic content (e.g. Hardisty 1944, Potter et al. 1986, Waterstraat \& Krappe 1998), presence of macrophytes (e.g. Potter et al. 1986, Waterstraat \& Krappe 1998), shading (e.g. Hardisty 1944, Potter et al. 1986, Waterstraat \& Krappe 1998) and water temperature (e.g. Morman et al. 1980) were also considered important in determining the distribution of the ammocoetes.

Studies on the distribution and habitat selection of larval lampreys in the Iberian Peninsula have mainly focused on sea lamprey (Rodríguez-Muñoz 2000,
Almeida \& Quintella 2002, Quintella et al. 2003, Cobo et al. 2010). Most of the unobstructed lengths of Iberian rivers run through low-slope landscapes, which makes larval habitats potentially more abundant than those required for nest building. On the Cantabrian coast, sea lamprey larvae are usually restricted to the middle and lower reaches of the main rivers, where suitable substrate of sand and clay are more common (Rodríguez-Muñoz 1992). In the River Sella (Cantabrian coast, northern Spain), larvae under $70 \mathrm{~mm}$ are more abundant in the middle than in the upper and lower river reaches, whereas no pattern was observed for larger larvae (Rodríguez-Muñoz 2000). In the River Mondego (central Portugal), sea lamprey ammocoete distribution is strongly dependent upon sediment particle size. Smaller individuals (20 to $60 \mathrm{~mm}$ ) are commonly found on silty, sand bottoms. Ammocoetes of 60 to $140 \mathrm{~mm}$ prefer a more heterogeneous substrate, with equal contributions of gravel and silt. Larger ammocoetes (140 to $200 \mathrm{~mm}$ ) prefer coarsegrained sediments of sand or gravelly-sand (Almeida \& Quintella 2002). In this river, possibly due to a severe reduction in the habitat available for adult sea lampreys, ammocoete abundance is higher in areas where spawning activities are observed (Almeida \& Quintella 2002).

In Europe, spawning in sea lampreys starts at $15^{\circ} \mathrm{C}$, whereas in river and brook lampreys it starts at 10 to $11^{\circ} \mathrm{C}$ (Hardisty \& Potter 1971). In the River Sella, sea lampreys spawn at water temperatures between 13 and $16^{\circ} \mathrm{C}$, and eggs hatch and survive at temperatures between 15 and $23^{\circ} \mathrm{C}$. Temperatures below this range limit survival (Rodríguez-Muñoz et al. 2001). Larvae from age $0+$ collected from the same river and maintained in the laboratory at different constant temperatures within the range of 5 to $30^{\circ} \mathrm{C}$ increased their body mass when reared between 15 and $27.5^{\circ} \mathrm{C}$ (Rodríguez-Muñoz 2000).

\section{Adults}

Typical spawning habitats for adults are generally found in upper river regions, in contrast with ammocoete habitats that are usually found more downstream (Waterstraat \& Krappe 1998). Ammocoetes release pheromones (bile acids) into the water, which play an important role in attracting anadromous adult lampreys towards those rivers containing larvae. Adult females are subsequently attracted to the spawning grounds by sexual pheromones released by mature males, the first to arrive and begin nesting activities (Hardisty 1986a). 
The 2 most important factors involved in the location of the spawning grounds are the presence of substrate suitable for the excavation of redds and relatively stable current flow. Both vary with the body size of the species. Larger lampreys, such as the sea lamprey, utilise sites where the gravels vary in diameter from 1.5 to $11.0 \mathrm{~cm}$, whereas smaller brook lampreys choose particle sizes smaller than $0.5 \mathrm{~cm}$ (Hardisty 1986a). Sea lampreys frequently spawn immediately downstream from weirs or other obstructions to upstream migration in strong currents (1 to $2 \mathrm{~m} \mathrm{~s}^{-1}$ ), whereas brook lampreys prefer sites with current velocity between 0.2 and $0.3 \mathrm{~m} \mathrm{~s}^{-1}$. Other variables such as stream order, stream size, water depth, shading and water temperature are also important in spawning site selection (Hardisty 1986a).

The spawning behaviour during the riverine adult phase of the parasitic Lampetra fluviatilis from the Iberian Peninsula is still poorly understood, mostly because of the impediments derived from the conservation status and small size of the single existent population. Results of a study on the spawning migration of this species using radio transmitters (ATS-Model 1415; dimensions: $0.5 \mathrm{~g}$ in air, $6 \mathrm{~mm}$ in diameter and $12 \mathrm{~mm}$ in length) in the River Almansor, a small tributary of the Tagus river basin (Almeida et al. 2011b), revealed that diurnal resting sites are generally found in covered locations near the banks, in sites with moderate water velocity $\left(0.22 \mathrm{~m} \mathrm{~s}^{-1}\right.$ on average), about $35 \mathrm{~cm}$ in depth and mainly sandy bottom. Upstream spawning migration was exclusively nocturnal, characterised by a discontinuous movement alternating between periods of migration and periods of stationary rest. Surprisingly, an apparently transposable weir made of loose stones was actually insurmountable for the upstream-migrating adults. In fact, the relatively small size of spawning adults from this population (ca. 25 to $30 \mathrm{~cm}$ total length and 30 to $40 \mathrm{~g}$ weight) suggests that their swimming capability is probably much lower than that of Petromyzon marinus. The migrating adults exhibited, on average, a swimming velocity of $0.40 \mathrm{~km} \mathrm{~h}^{-1}$ (1566 body lengths $\mathrm{h}^{-1}$ ). This study was conducted for $3 \mathrm{yr}$, and during that period, only 12 adult river lampreys were caught, which is indicative of the rareness of this population (Almeida et al. 2011b).

\section{LEGISLATION AND PROTECTION}

The 3 lamprey species are listed in Annex III (protected fauna species) of the Bern Convention (Convention on the Conservation of European Wildlife and Natural Habitats) and in Annex II of the European Union Habitats Directive (92/43/EEC), which lists animal and plant species of interest to the European Community whose conservation requires the designation of Special Areas of Conservation (SACs) by the member states. Petromyzon marinus is listed in the OSPAR convention list (Convention for the Protection of the Marine Environment of the NorthEast Atlantic) of threatened and/or declining species, and their European populations are protected by Annex B-II of the European Habitats Directive and Annex III of the Bern Convention. The river lamprey is also listed in Annex $\mathrm{V}$ of the Habitats Directive, which lists animal and plant species of community interest, for which capture and exploitation may be controlled by management measures.

According to the Habitats directive, a SAC is a site of Community importance designated by the Member States through a statutory, administrative and/or contractual act where the necessary conservation measures are applied for the maintenance or restoration, at a favourable conservation status, of the natural habitats and/or the populations of the species for which the site is designated. These areas are then associated in a European ecological network called Natura 2000. This network, composed of sites hosting the natural habitat types listed in Annex I and habitats of the species listed in Annex II of the Habitats Directive, shall enable the natural habitat types and the species' habitats concerned to be maintained or, where appropriate, restored at a favourable conservation status in their natural range. The SACs for lampreys should be characterised by good water quality, clean coarse substrate at spawning grounds and the presence of fine sand/silt sediment downstream of spawning areas which may constitute ammocoete beds. Access from the sea to spawning areas must also be ensured for anadromous lampreys. Following this directive, several countries have already defined sites important for lamprey species to form part of the Natura 2000 network. For example, in 2004, Germany proposed a number of SACs in German Baltic waters to the EU Commission. These SACs cover parts of the estuarine Szczecin Lagoon and adjacent waters, covering the main migration route of river lampreys to their most numerous spawning sites (Thiel et al. 2009). Also, a list of SACs for sea, brook and river lampreys has been proposed for Ireland (Kelly \& King 2001). The designated sites give particular emphasis to channels in which the 3 species are known to co-occur. Similarly, the primary reason for the selection of the River Teith (Scotland) to be proposed as a SAC was that, unlike many other 
British rivers, it supports populations of all 3 lamprey species (Maitland \& Lyle 2003). When species co-occur, since many of the habitat requirements of the 3 species are the same, particularly during the larval phase, the creation of SACs should benefit all 3 species (Maitland 2004). In France, 84 Natura 2000 sites were designated due to, among other reasons, their importance to Petromyzon marinus. For Lampetra fluviatilis and L. planeri, 49 and 215 Natura 2000 sites, respectively, were defined in France (Muséum National d'Histoire Naturelle 2003-2012).

For the genus Lampetra in Portugal, following an extensive sampling campaign where the presence and abundance of larvae were related to the characteristics of the habitat, a total of 31 river stretches from 8 river basins with the potential to be designated as SACs were identified (Almeida et al. 2011a). Ten locations have been selected to be proposed as SACs only in the Tagus basin, of which 8 presumably support populations of the 3 species, as no obstacle to the migration of the 2 anadromous species is known to occur. However, site designation by the proper authorities will not be sufficient to ensure the conservation and protection of this genus, classified with the most threatened conservation status (Critically Endangered), as management actions will be required to ensure their conservation.

In the Iberian Peninsula, besides the classification in the threatened category of the Red Lists of both Portugal and Spain (Doadrio 2001, Cabral et al. 2005), the 3 species are protected by several laws. In Portugal, all 3 species are included in the following laws: decree no. 140/99 (DR 1999), Appendix B-II (and B-V for the river lamprey), transposition to the Portuguese legislation of the Habitats Directive (92/43/CEE), 21 May; decree no. 316/89 (DR 1989), transposition to the Portuguese legislation of the Bern Convention (Appendix III); law no. 7/2008, which governs fishing activities in inland waters (DR 2008), and respective publication of regulations. Additionally, the sea lamprey, as an important economic resource in Portugal, is also protected by the following: decree no. $43 / 87$ (DR 1987) and decree no. 7/2000, which governs fishing activities in non-oceanic inland waters (DR 2000), and complementary legislation for each river basin. In general, the fishing period for the sea lamprey is established between the beginning of January and the end of April. Captures are limited to lampreys over $350 \mathrm{~mm}$ in body length and to a maximum of 30 ind. $\mathrm{d}^{-1}$ for each fisherman. In river basins where the species is less abundant, the quota is lower (e.g. 6 specimens in the River Guadiana and 10 specimens in the Rivers Vouga and Cávado for the year 2011).
In Spain, all 3 species are listed for protection under decree no. 1997/95 (BOE 1995), Appendix B-II (and $\mathrm{B}-\mathrm{V}$ for the river lamprey), transposition to the Spanish legislation of the Habitats Directive (92/43/CEE). The sea lamprey is included in decree no. 1095/89 (BOE 1989a), which determines the species subject to fisheries and hunting in Spain and the regulations that assure their protection, and decree no. 1118/89 (BOE 1989b), which determines commercial species subject to fisheries and hunting and the related rules. Laws no. 8/98 (DOE 1998) and 9/2006 (DOE 2006) protect threatened species of the Autonomic Region of Extremadura and their habitats. Recently, decree no. 139/2011 (BOE 2011) classified Lampetra planeri as Vulnerable in Spain. Petromyzon marinus has been classified as Endangered, but this applies only to populations from the Rivers Guadiana, Guadalquivir, Ebro and those from the socalled southern basins. However, Doadrio (2001) classified $L$. planeri as Critically Endangered due to the existence of a single small population in Spain (the only confirmed population at the time), which is declining due to the reduction of available spawning habitat.

Sea lamprey fisheries still persist in Galicia, where captures are allowed in the Rivers Tea and Ulla (DOG 2011). In the autonomic regions, this species is classified as follows: Vulnerable in the List of Threatened Species of Galicia, law no. 9/2001 (BOE 2001) and decree no. 88/2007 (DOG 2007); Endangered in the List of Threatened Species of Extremadura (Fallola et al. 2010a); Protected species of the autochthonous wild fauna of Cataluña, law no. 12/2006 (DOGC 2006); and Vulnerable in the Catalogue of Threatened Species of Vertebrates of Asturias, decree no. 32/90 (BOPA 1990).

The brook lamprey is considered Of Special Interest in Navarra according to the Catalogue of Threatened Species of Navarra, decree no. 563/95 (BON 1995), and the river lamprey is considered Regionally Extinct in Extremadura (Fallola et al. 2010b).

\section{FACTORS CONTRIBUTING TO POPULATION DECLINES}

European populations of sea lamprey have declined dramatically over the last $25 \mathrm{yr}$ (Lelek 1987), and several authors have pointed out a reduction in sea lamprey abundance in Iberian rivers (e.g. Guimarães 1988, Almaça 1990, Assis 1990, Granado-Lorencio 1991, Almeida \& Quintella 2002). This decline is also severe in the other 2 species occurring on the Iberian 
Peninsula, the river and brook lampreys, and several factors contribute to this reduction.

\section{River impoundments}

Habitat fragmentation and reduction by construction of large dams, weirs and other man-made barriers are among the main threats to lamprey populations both in Portugal (Cabral et al. 2005) and Spain (Doadrio 2001). The 2 anadromous species are severely affected by this activity, which has fewer effects on the brook lamprey due to its non-migratory ecology. Table 2 shows the percentage of habitat lost with the construction of dams in the lower stretches of all the major basins, and on average $80 \%$ of the habitat that was historically used by lampreys in each river basin is now unavailable.

Dams and weirs block the longitudinal continuity of a river, limiting the access of adults to suitable spawning grounds. This reduces the available habitat for adults to spawn and for the growth and development of ammocoetes (Table 2, Fig. 2). Spawning grounds are usually located in upstream reaches, where temperature and oxygen conditions are suitable for spawning, egg incubation and early larval development. In a study on sea lamprey in the River Mondego (central Portugal), Quintella et al. (2003) observed that the abundance of ammocoetes was higher in areas around sea lamprey nests, due to the severe reduction in the area available for both spawning and larval growth. In this river, the sea lamprey is confined to the lower $35 \mathrm{~km}$, and adults concentrate to spawn in the uppermost $5 \mathrm{~km}$ downstream from the Açude-Ponte dam.

On the Iberian Peninsula, most of the dams and weirs were built in the second half of the last century (Santo 2005, Cea Azañedo \& Sánchez Cabezas 2007). During this period, about 20 dams $\mathrm{yr}^{-1}$ were constructed in Spain, and fish migration was blocked at most of the major Spanish rivers (Cea Azañedo \& Sánchez Cabezas 2007). Portuguese rivers are impounded by 166 dams and more than 3000 small weirs (Quintella 2006). The number of weirs and dams with fish passes is extremely low in Portugal, and only a small percentage of the fish passes installed are still functional (Santo 2005).

\section{Pollution}

First signs of river pollution caused by human activities have been timed around 5000 yr ago (Davis et al. 2000), but it is not until the dramatic increase in mining, industrial and urban development that water contamination became the key and widespread problem we experience at present (Prenda Marín et al. 2006, Gros et al. 2007, Lorenzo et al. 2007). The beginning of the industrial era during the 19th century set the start of the decline of Spanish river ecosystems (Pérez Cebada 2008).

Lampreys are known to be sensitive to pollution and, although few data are available, entire populations probably disappeared from rivers that became polluted. This is most likely the case of the River Ave in northern Portugal (Quintella 2006), where sea lampreys were once considered common by Baldaque da Silva (1891) and have now vanished. Industrial pollution is probably also responsible for the extremely low density of sea lamprey larvae populations in the lower reaches of the River Cávado (Almeida et al. 2008). Anadromous species are especially affected by pollution barriers during their spawning migration, but in the larval phase, both resident and anadromous species are affected.

\section{Dredging and habitat destruction}

Besides the loss of spawning and larval habitats caused by dams and weirs, several other anthropogenic actions may modify the physiographic features of rivers and streams. Sand extraction may drastically modify riverbeds and cause the destruction of larval habitats; it is therefore considered to be among the main threats to lamprey larval stages (Quintella et al. 2007). Dredging also causes the removal of areas of riffles and associated spawning gravels, which will disturb the spawning activity of the lampreys. Channel and bank regulation can also cause the destruction of suitable spawning and larval habitats through removal of areas of riffles and dredging of suitable silt beds, respectively, and it can eliminate populations from entire river stretches.

\section{Commercial exploitation}

On the Iberian Peninsula, overfishing from commercial harvesting is a serious threat for Petromyzon marinus, particularly in the central and northern regions (Renaud 1997, Doadrio 2001, Cabral et al. 2005). The high economic value of the sea lamprey in Portugal and some Spanish regions makes them a preferred target for both poaching and legal fisheries, creating a major threat to the sustainability and 
conservation of this species. The fishing gears traditionally used by professional fishermen to harvest adult sea lampreys in Portugal are drift trammel nets and large fyke nets (Quintella 2006).

The gastronomic importance of sea lampreys is reflected by their high commercial value, which can easily reach $€ 50$ per animal during the peak of the season (Quintella 2006). Sea lampreys are sold directly to restaurants or intermediaries without being taxed. For that reason, the official records of sea lamprey captures are far from being realistic. In the River Mondego (central Portugal), a study by Duarte et al. (2003) to assess the catch rate of a large fyke net used to harvest sea lampreys in the estuary is indicative of the number of animals that are captured annually. During the 2002 spawning season, between 6 January and 13 April, 555 lampreys were captured by a single fyke net with a catch rate of 7.4 ind. tide $^{-1}(12 \mathrm{~h})$. The same authors gathered additional unverified information about the catch rates of 6 local fishermen who used the same fishing gear. Between January and April 2002, in a total of 6 nets, 2846 lampreys were captured. These numbers are reflective of the threat that this activity, if not properly regulated, may pose to the survival of the exploited sea lamprey populations. The impact of poachers is also not negligible in Portuguese rivers. In a study by Andrade et al. (2007) that was aimed at investigating the spawning migration of sea lampreys in the Vouga basin (central Portugal) via radio telemetry, $76 \%$ of the tagged lampreys were recaptured by poachers, who delivered the transmitters to the researchers involved in the study in exchange for a $€ 50$ reward.

\section{Climate change and water availability}

Most Iberian rivers are within the temperature and oxygen concentration ranges required to sustain lamprey populations. However, a shift in these ranges due to global warming, especially in the southern basins, may cause the local extinction of lamprey populations. For Lampetra planeri, Hardisty (1961) found that even when spawning activity is well under way, a sudden but slight drop in temperature has often resulted in the almost complete disappearance of lamprey adults from the nests.

In a recent study, Lassalle et al. (2008) projected that, under a climate change scenario, by the end of the 21st century Petromyzon marinus will show a decrease in the basins bordering the east coast of the Adriatic Sea, in most of the Italian basins and in the
Iberian Peninsula. The authors calculated that this species can disappear from the largest basins in the south of the Iberian Peninsula, remaining present only in the northern Minho basin. As the predictive model for this species included both temperature and precipitation as explanatory variables, a change in climate is projected to severely negatively affect the distribution of this species in its southern limit (Lassalle et al. 2008).

Populations in the southern distribution of these species are inherently at risk of extinction because in addition to anthropogenic pressures, these basins are situated in a region at risk of being significantly affected by climate change. In the southern basins, where water availability is often critical during the summer period, activities such as water abstraction accentuate the pollution impact by diminishing the dilution capacity of the streams. This may be particularly alarming in the Sado basin, which represents the southern distribution of Lampetra. The population inhabiting this basin has been classified as an ESU by Mateus et al. (2011a), constituting an important source of genetic variability, and should be prioritised in terms of conservation.

\section{FINAL REMARKS AND RECOMMENDATIONS}

On the Iberian Peninsula, like in many countries, the 3 species are classified as threatened (i.e. Critically Endangered, Endangered or Vulnerable. see Table 1). Based on genetic analyses that suggest differentiation between European and North American sea lamprey populations (Rodríguez-Muñoz et al. 2004), we recommend that European and North American sea lampreys be considered as different populations that should be managed independently. In view of that, and considering its conservation status in the countries holding the main populations (i.e. France, Spain and Portugal), we propose that the European population of Petromyzon marinus be revised to a threat category in the IUCN Red List. Also, we recommend that the conservation units identified by Mateus et al. (2011a) for Iberian populations of Lampetra fluviatilis and L. planeri, following mitochondrial DNA analysis, be considered in future IUCN Red List revisions.

The recently confirmed presence of the genus Lampetra in a river basin in Asturias (Mateus et al. $2011 b$ ) is indicative that this genus may occur in other rivers from this Spanish region and possibly in neighbouring regions like Galicia and Cantabria. Further data on the distribution of Lampetra in Spain 
is needed, especially in these regions, where its presence is expected.

During the larval phase, the 3 species occupy similar (often the same) habitats. Thus, factors that affect 1 species are likely to affect the other 2. Similarly, conservation requirements to enhance and restore populations are likely to be very similar for all 3 species (Maitland \& Lyle 2003). Petromyzon marinus and Lampetra fluviatilis, however, require a pathway from their adult feeding grounds in the marine environment to their spawning grounds, whereas $L$. planeri is a purely freshwater species, requiring access only between larval and spawning habitats. One of the main problems in the adult phase of migratory species is related to river impoundments, since the habitat that was historically used by these species is now unavailable. Based on historical records of lampreys in the upper reaches of the main river basins, we quantified range contraction caused by the construction of insurmountable obstacles in the lower reaches of most rivers to be no less than $80 \%$ of the original area. In the River Douro, the largest basin on the Iberian Peninsula, the loss was $96 \%$, since the first dam is located just $20 \mathrm{~km}$ from the river mouth (Table 2, Fig. 2). Management should focus on unblocking the lower stretches of all major river basins, so that adult and juvenile migration can be resumed. Unblocking can be accomplished by either the removal of barriers and weirs or the construction of functional fish passages in rivers where spawning and larval habitats are situated. Delimiting viable areas suitable to be used by ammocoetes, in conjunction with the restriction of economic activities such as sand extraction, can be effective conservation measures for the protection of larval habitats (Quintella et al. 2007).

From data obtained through a predictive distribution model of the genus Lampetra in Portugal, Almeida et al. (2011a) identified a number of river stretches with the potential to become SACs. These cover the main migratory routes of river lampreys to their most numerous spawning sites and the most suitable larvae habitats for both river and brook lampreys. The identification of protected areas constitutes an important measure for the conservation of these species in Iberian rivers, and is particularly important for the protection of the single Iberian population of European river lampreys. Efforts should be made to restore lost spawning sites and the connectivity between them, as well as the nursery habitats. Such efforts would benefit all 3 species. The identification of conservation units following molecular studies (e.g. Mateus et al. 2011a) is also of great impor- tance to support plans focused on the maintenance of gene flow and the preservation of gene diversity.

In Portugal and some regions of Spain, the sea lamprey is a species with high economic value. In Portugal, it supports commercial fisheries in most of the major river systems. Despite the actual legislation controlling fisheries, this activity may lead to an overexploitation of this resource. Promoting the sustainable management of commercial exploitation can minimise the negative impacts of fisheries. It is important to gather reliable records of the professional captures in each river basin where this species occurs, and professional fishing regulations should be reviewed according to scientific background information.

Lamprey populations from the southern basins are particularly vulnerable to climate changes, and additional efforts should be taken when implementing management plans. In these basins, actions causing hydraulic stress and pollution should be the first to be minimised. Knowledge on the effects of pollution is very scarce, and research needs to be done to identify important pollution problems and their geographical location, so that actions to reduce or eliminate contamination sources can be implemented.

Acknowledgements. We thank M. Ćaleta, U. Gärdenfors, E. Thorstad, M. Ovidio, P. Wind and P.G. Bianco for information on the conservation status of lampreys in Croatia, Sweden, Norway, Belgium, Denmark and Italy, respectively. T. Virbickas and R. Repecka provided information on lampreys from Lithuania. We are grateful to the Associate Editor S. Cooke and to the anonymous reviewers, who greatly improved the manuscript with their comments and suggestions. This work was financially supported by Fundação para a Ciência e a Tecnologia (FCT) through project funding (PTDC/BIA-BEC/103258/2008), through its pluriannual funding program to the Centre of Oceanography (PEst-OE/ MAR/UI0199/2011), and through a PhD grant to C.S. Mateus (SFRH/BD44029/2008). Thanks are also due to Energias de Portugal (EDP), which attributed the award 'Fundo EDP Biodiversidade 2008', and to the Lisbon Oceanarium through project funding.

\section{LITERATURE CITED}

Abel A (1998) Las pesquerías del alto Miño y afluentes en el siglo XVIII. Bol Mus Prov Lugo 8:159-178

Almaça C (1990) A lampreia e o esturjão na bacia do Douro. Observatório 1:377-382

Almaça C, Collares-Pereira MJ (1988) On the occurrence of the European river lamprey, Lampetra fluviatilis L., in the Iberian Peninsula. Cybium 12:9-15

Almeida PR, Quintella BR (2002) Larval habitat of the sea lamprey (Petromyzon marinus L.) in the river Mondego (Portugal). In: Collares-Pereira MJ, Coelho MM, Crowx IG (eds) Freshwater fish conservation: options for the 
future. Fishing News Books, Blackwell Science, Oxford, p 121-130

Almeida PR, Silva HT, Quintella BR (2000) The migratory behaviour of the sea lamprey Petromyzon marinus L., observed by acoustic telemetry in River Mondego (Portugal). In: Moore A, Russell I (eds) Advances in fish telemetry. CEFAS, Lowestoft, p 99-108

Almeida PR, Quintella BR, Dias NM (2002) Movement of radio-tagged anadromous sea lamprey during the spawning migration in the River Mondego (Portugal). Hydrobiologia 483:1-8

Almeida PR, Tomaz G, Andrade NO, Quintella BR (2008) Morphological analysis of geographic variation of sea lamprey ammocoetes in Portuguese river basins. Hydrobiologia 602:47-59

Almeida PR, Maia C, Quintella BR, Antunes C and others (2011a) Plano de conservação da lampreia-de-rio e da lampreia-de-riacho. Final Report. EDP-Energias de Portugal, Lisbon

Almeida PR, Quintella BR, Mateus CS, Alexandre CM, Pereira TJ, Ferreira AF, Encarnação C (2011b) Monitorização da migração reprodutora da lampreia-de-rio (Lampetra fluviatilis L.) na sub-bacia hidrográfica do Rio Sorraia. Final report. Lisbon Oceanarium, Lisbon

Andrade NO, Quintella BR, Ferreira J, Pinela S, Almeida PR (2007) Sea lamprey (Petromyzon marinus L.) spawning migration in the Vouga river basin (Portugal): poaching impact, preferential resting sites and spawning grounds. Hydrobiologia 582:121-132

Assis CA (1990) Threats to the survival of anadromous fishes in the River Tagus, Portugal. J Fish Biol 37:225-226

Baldaque da Silva AA (1891) Estado actual das pescas de Portugal. Imprensa Nacional, Lisbon

Baxter EW (1957) Lamprey distribution in streams and rivers. Nature 180:1145

Bianco PG, Delmastro GB (2011) Recenti novità tassonomiche riguardanti i pesci d'acqua dolce autoctoni in Italia e descrizione di una nuova specie di luccio. In: de Filippo G (ed) Researches on wildlife conservation 2 (Suppl). IGF Publishing

Bianco PG, Ketmaier V, Soto E, de Filippo G (2011) Gli agnati e i gamberi nel Parco Nazionale del Cilento e Vallo di Diano. In: Bianco PG, de Filippo G (eds) Contributo alla conoscenza della fauna ittica d'acqua dolce in aree protette d'Italia. Researches on wildlife conservation 3. IGF Publishing

Blank M, Jürss K, Bastrop R (2008) A mitochondrial multigene approach contributing to the systematics of the brook and river lampreys and the phylogenetic position of Eudontomyzon mariae. Can J Fish Aquat Sci 65:2780-2790

BOE (1989a) Real Decreto 1095/89 de 8 de Septiembre. Boletín Oficial del Estado 218. Ministerio de Agricultura, Pesca y Alimentación, Madrid, p 28819-28821

BOE (1989b) Real Decreto 1118/89 de 15 de Septiembre. Boletín Oficial del Estado 224. Ministerio de Agricultura, Pesca y Alimentación, Madrid, p 29453-29454

BOE (1995) Real Decreto 1997/95 de 7 de Diciembre. Boletín Oficial del Estado 310. Ministerio de Agricultura, Pesca y Alimentación, Madrid, p 37310-37333

BOE (2001) Ley 9/2001 de 21 de Agosto. Boletín Oficial del Estado 230. Parlamento de Galicia, Santiago de Compostela, p 35529-35542

BOE (2011) Real Decreto 139/2011 de 4 de Febrero. Boletín Oficial del Estado 46. Ministerio de Medio Ambiente, y Medio Rural y Marino, Madrid, p 20912-20951
BON (1995) Decreto Foral 563/95 de 27 de Noviembre. Boletín Oficial de Navarra 156. Gobierno de Navarra, Consejería de Medio Ambiente, Ordenación del Territorio e Vivienda, Pamplona

BOPA (1990) Decreto 32/90 de 8 de Marzo. Boletín Oficial del Principado de Asturias y de la Provincia 75. Principado de Asturias, Consejería de la Presidencia, Oviedo, p 1387-1389

Boutellier P (1918) La pêche maritime au Maroc (Casablanca, Fédala, Rabat). G. Mercié \& Co., Casablanca

Bryan MB, Zalinski D, Filcek KB, Libants S, Li W, Scribner KT (2005) Patterns of invasion and colonization of the sea lamprey (Petromyzon marinus) in North America as revealed by microsatellite genotypes. Mol Ecol 14: 3757-3773

Cabral MJ, Almeida J, Almeida PR, Dellinger T and others (eds) (2005) Livro vermelho dos vertebrados de Portugal. Instituto de Conservação da Natureza, Lisbon

Carl H, Berg S, Møller PR, Rasmussen G, Nielsen JG (2004) Freshwater fish. In: Wind P, Pihl S (eds) The Danish red list. The National Environmental Research Institute, Aarhus University, Aarhus

Cea Azañedo JC, Sánchez Cabezas FJ (2007) El inventario de presas españolas de 2006 y síntesis de la actividad de construcción de presas en España en el trienio 20042006. Rev Obras Públ 3475:93-115

Cevik C, Ergueden D, Tekelioglu N (2010) Confirmation of the presence of the sea lamprey, Petromyzon marinus Linnaeus, 1758 in the Levantine Sea (Petromyzoniformes: Petromyzonidae). Zool Middle East 49:107

Cobo F, Silva S, Vieira-Lanero R, Servia MJ and others (2010) Estado de conservación das poboacións de lamprea mariña (Petromyzon marinus Linnaeus, 1758) en ríos de Galicia. Xunta de Galicia, Consellería do Medio Rural, Dirección Xeral de Conservation da Natureza, Santiago de Compostela

Davis RA Jr, Welty AT, Borrego J, Morales JA, Pendon JG, Ryan JG (2000) Rio Tinto estuary (Spain): 5000 years of pollution. Environ Geol (Berl) 39:1107-1116

Doadrio I (2001) Atlas y libro rojo de los peces continentales de España. Dirección General de Conservación de la Naturaleza, Museo Nacional de Ciencias Naturales, Madrid

Docker MF (2009) A review of the evolution of nonparasitism in lampreys and an update of the paired species concept. In: Brown LR, Chase SD, Mesa MG, Beamish RJ, Moyle PB (eds) Biology, management, and conservation of lampreys in North America. Am Fish Soc Symp 72. AFS, Bethesda, MD, p 71-114

> Docker MF, Youson JH, Beamish RJ, Devlin RH (1999) Phylogeny of the lamprey genus Lampetra inferred from mitochondrial cytochrome $b$ and ND3 gene sequences. Can J Fish Aquat Sci 56:2340-2349

DOE (1998) Ley 8/98 de 26 de Junio. Diario Oficial de Extremadura 86. Junta de Extremadura, Mérida, p 5914-5943

DOE (2006) Ley 9/2006 de 23 de Diciembre. Diario Oficial de Extremadura 153. Junta de Extremadura, Mérida, p 21708-21719

DOG (2007) Decreto 88/2007 de 19 de Abril. Diario Oficial de Galicia 89. Xunta de Galicia, Consellería de Medio Ambiente e Desenvolvemento Sostible, Santiago de Compostela, p 7409-7423

DOG (2011) Orde do 28 de xaneiro de 2011. Diario Oficial de Galicia 22. Xunta de Galicia, Consellería do Medio Rural, Santiago de Compostela, p 1828-1853 
DOGC (2006) Ley 12/2006 de 27 de Julio. Diari Oficial de la Generalitat de Catalunya 4690. Generalidad de Cataluña, Consejería de Medio Ambiente e Vivienda, Barcelona, p 34423-34430

Dollfus RP (1955) Première contribution à l'établissement d'un Fichier ichthyologique du Maroc atlantique. Trav Inst Sci Chérifien, Sér Zool 6:1-226

DR (1987) Decreto Regulamentar 43/87 de 17 de Julho. Diário da República (Série I) 162. Ministério da Agricultura, Pescas e Alimentação, Lisbon, p 2814-2830

DR (1989) Decreto-lei 316/89 de 22 de Setembro. Diário da República (Série I) 219. Ministério do Planeamento e da Administração do Território, Lisbon, p 4224-4227

DR (1999) Decreto-lei 140/99 de 24 de Abril. Diário da República (Série I) 96. Ministério do Ambiente, Lisbon, p 2183-2212

DR (2000) Decreto Regulamentar 7/2000 de 30 de Maio. Diário da República (Série I) 125. Ministério da Agricultura, do Desenvolvimento Rural e das Pescas, Lisbon, p 2494-2509

DR (2008) Lei 7/2008 de 15 de Fevereiro. Diário da República (Série I) 33. Assembleia da República, Lisbon, p 1024-1032

Duarte ACL, Jorge I, Sobral MP, Rebordão FR, Martins R, Carneiro M (2003) Rendimento do botirão usado na captura da lampreia Petromyzon marinus L. 1758 no estuário do Rio Mondego. Relatórios Científicos e Técnicos do IPIMAR, Série digital 8, IPIMAR, Lisbon

Economidis PS, Kallianiotis A, Psaltopoulou H (1999) Two records of sea lamprey from the north Aegean Sea. J Fish Biol 55:1114-1118

Elvira B (2004) La ictiofauna del Guadiana: un patrimonio amenazado. In: Martínez-Gil FJ (ed) Una nueva cultura del agua para el Guadiana. Desde Ruidera a Ayamonte. Fundación Nueva Cultura del Agua, Zaragoza, p 409-418

Eneqvist P (1937) The brook lamprey as an ecological modification of the river lamprey. On the river and brook lampreys of Sweden. Ark Zool 29:1-22

Erguven H (1989) An investigation on the determination of the parasitic form of Petromyzonidae living in the streams running to Sepanca Lake. Su Urunleri Dergisi/J Aquat Prod 3:29-36

Escolar N (1865) Ensayo monográfico de las aguas y baños minero-medicinales de Riva los Baños en la villa de Torrecilla de Cameros. Imprenta Médica de Manuel Álvarez, Madrid

Espanhol R, Almeida PR, Alves MJ (2007) Evolutionary history of lamprey paired species Lampetra fluviatilis (L.) and Lampetra planeri (Bloch) as inferred from mitochondrial DNA variation. Mol Ecol 16:1909-1924

Fallola C, Moreno P, Pérez JJ, Pula HJ, Ramírez JC, Roldán F, Velasco R (2010a) Petromyzon marinus (Linnaeus, 1758). In: Palacios MJ, Pérez J, Sánchez A, Muñoz P (coords) Catálogo regional de especies amenazadas de Extremadura. Fauna I. Junta de Extremadura, Consejería de Industria, Energía y Medio Ambiente, Mérido, p 96-97

Fallola C, Moreno P, Pérez JJ, Pula HJ, Ramírez JC, Roldán F, Velasco R (2010b) Lampetra fluviatilis (Linnaeus, 1758). In: Palacios MJ, Pérez J, Sánchez A, Muñoz $P$ (coords) Catálogo regional de especies amenazadas de Extremadura. Fauna I. Junta de Extremadura, Consejería de Industria, Energía y Medio Ambiente, Mérido, p 98
Fernández Pasquier V (1999) Acipenser sturio L. in the Guadalquivir River, Spain. Water regulation and fishery as factors in stock decline from 1932 to 1967. J Appl Ichthyol 15:133-135

Freyhof J (2002) Freshwater fish diversity in Germany, threats and species extinction. In: Collares-Pereira MJ, Coelho MM, Crowx IG (eds) Freshwater fish conservation: options for the future. Fishing News Books, Blackwell Science, Oxford, p 3-22

Freyhof J, Brooks E (2011) European Red List of freshwater fishes. Publications Office of the European Union, Luxembourg

Freyhof J, Kottelat M (2008a) Lampetra planeri. In: IUCN red list of threatened species. Version 2010.4. Available at www.iucnredlist.org (accessed on 18 January 2012)

Freyhof J, Kottelat M (2008b) Lampetra fluviatilis. In: IUCN red list of threatened species. Version 2010.4. Available at www.iucnredlist.org (accessed on 18 January 2012)

Freyhof J, Kottelat M (2008c) Petromyzon marinus. In: IUCN red list of threatened species. Version 2010.4. Available at www.iucnredlist.org (accessed on 18 January 2012)

Frutos MP (2011) Rebollo, paisajes, estampas y costumbres. Aebius, Madrid

Gärdenfors U (ed) (2010) The 2010 red list of Swedish species. ArtDatabanken, SLU, Uppsala

Gibert AM (1912) Fauna ictiológica de Cataluña. Catalech rahonat dels pexos observats en el litoral y en les aygues dolces catalanes. Butll Inst Catal Hist Nat (2 epoca) 8: 138-157

Gill HS, Renaud CB, Chapleau F, Mayden RL, Potter IC (2003) Phylogeny of living parasitic lampreys (Petromyzontiformes) based on morphological data. Copeia 2003: 687-703

Głowaciński Z, Makomaska-Juchiewicz M, PołczyńskaKonior G (eds) (2002) Red list of threatened animals in Poland. Instytut Ochrony Przyrody PAN, Kraków

Gómez A, Lunt DH (2006) Refugia within refugia: patterns of phylogeographic concordance in the Iberian Peninsula. In: Weiss S, Ferrand N (eds) Phylogeography of southern European refugia. Springer, Dordrecht, p 155-188

Granado-Lorencio C (1991) The effect of man on the fish fauna of the River Guadalquivir, Spain. Fish Res 12: 91-100

Granado-Lorencio C (1996) Ecología de peces. Universidad de Sevilla, Serie Ciencias 45. Grafitrés, SL-Utrera, Sevilla

Gros M, Petrovi M, Barceló D (2007) Wastewater treatment plants as a pathway for aquatic contamination by pharmaceuticals in the Ebro river basin (northeast Spain). Environ Toxicol Chem 26:1553-1562

Guimarães MT (1988) Medidas para a protecção e fomento da lampreia do mar (Petromyzon marinus L.) no rio Mondego. In: Actas do Colóquio Luso-Espanhol sobre Ecologia das Bacias Hidrográficas e Recursos Zoológicos. Instituto de Zoologia e Estação de Zoologia Marítima Dr. Augusto Nobre, Porto, p 195-203

Hardisty MW (1944) The life history and growth of the brook lamprey (Lampetra planeri). J Anim Ecol 13:110-122

> Hardisty MW (1961) The growth of larval lampreys. J Anim Ecol 30:357-371

Hardisty MW (1979) Biology of the Cyclostomes. Chapman and Hall, London

Hardisty MW (1986a) General introduction to lampreys. In: Holčík J (ed) The freshwater fishes of Europe. Vol 1, Part I - Petromyzontiformes. Aula-Verlag, Wiesbaden, p 19-83 
Hardisty MW (1986b) Petromyzon marinus (Linnaeus, 1758). In: Holčík J (ed) The freshwater fishes of Europe. Vol 1, Part I - Petromyzontiformes. Aula-Verlag, Wiesbaden, p 94-116

Hardisty MW (1986c) Lampetra fluviatilis (Linnaeus, 1758). In: Holčík J (ed) The freshwater fishes of Europe. Vol 1, Part I - Petromyzontiformes. AulaVerlag, Wiesbaden, p 249-278

Hardisty MW (1986d) Lampetra planeri (Bloch, 1758). In: Holčík J (ed) The freshwater fishes of Europe. Vol 1, Part I - Petromyzontiformes. Aula-Verlag, Wiesbaden, p 279-304

Hardisty MW, Potter IC (1971) The behaviour, ecology and growth of larval lampreys. In: Hardisty MW, Potter IC (eds) The biology of lampreys, Vol 1. Academic Press, London, p 85-125

Hubbs CL, Potter IC (1971) Distribution, phylogeny and taxonomy. In: Hardisty MW, Potter IC (eds) The biology of lampreys, Vol 1. Academic Press, New York, NY, p 1-65

Hubert N, Hanner R, Holm E, Mandrak NE and others (2008) Identifying Canadian freshwater fishes through DNA barcodes. PLoS ONE 3:e2490

IUCN France, MNHN, SFI, ONEMA (2010) La liste rouge des espèces menacées en France - poissons d'eau douce de France métropolitaine. IUCN, Paris. Available at www. uicn.fr/IMG/pdf/Liste_rouge_France_Poissons_d_eau_ douce_de_metropole.pdf

Kålås JA, Viken Å, Henriksen S, Skjelseth S (eds) (2010) The 2010 Norwegian red list for species. Norwegian Biodiversity Information Centre, Trondheim

Kaukoranta M, Koljonen ML, Koskiniemi J, Tammi J (2000) Atlas of Finnish fishes, English summary. Distribution of lamprey, brook lamprey, Atlantic salmon, brown trout, Arctic charr, whitefish, vendace, grayling, asp, vimba, spined loach and bullhead - the distribution and status of stocks. Finnish Game and Fisheries Research Institute, Helsinki

Kelly FL, King JJ (2001) A review of the ecology and distribution of three lamprey species, Lampetra fluviatilis (L.), Lampetra planeri (Bloch) and Petromyzon marinus (L.): a context for conservation and biodiversity considerations in Ireland. Biol Environ: Proc R Ir Acad 101B:165-185

Kestemont B (2010) A red list of Belgian threatened species. Statistics Belgium, Brussels

Kirchhofer A, Breitenstein M, Zaugg B (2007) Liste rouge poissons et cyclostomes - Liste rouge des espèces menacées en Suisse. L'environnement pratique No. 0734. Office fédéral de l'environnement, Berne, et Centre suisse de cartographie de la faune, Neuchâtel

Kottelat M, Freyhof J (2007) Handbook of European freshwater fishes. Kottelat, Cornol and Freyhof, Berlin

Lang NJ, Roe KJ, Renaud CB, Gill HS and others (2009) Novel relationships among lampreys (Petromyzontiformes) revealed by a taxonomically comprehensive molecular data set. In: Brown LR, Chase SD, Mesa MG, Beamish RJ, Moyle PB (eds) Biology, management, and conservation of lampreys in North America. Am Fish Soc Symp 72. AFS, Bethesda, MD, p 41-56

Lassalle G, Béguer M, Beaulaton L, Rochard E (2008) Diadromous fish conservation plans need to consider global warming issues: an approach using biogeographical models. Biol Conserv 141:1105-1118

Lelek A (1987) The freshwater fishes of Europe Vol 9. Threatened fishes of Europe. Aula-Verlag, Wiesbaden

Lilleleht V, Ernits P, Hang V, Ingerpuu N and others (2008)
Estonian red data book. Estonian Academy of Sciences, Commission for Nature Conservation, Tartu

Lorenzo F, Alonso A, Pellicer M, Pagés J, Pérez-Arlucea M (2007) Historical analysis of heavy metal pollution in three estuaries on the north coast of Galicia (NW Spain). Environ Geol (Berl) 52:789-802

Lusk S, Hanel L, Lusková V (2004) Red list of the ichthyofauna of the Czech Republic: development and present status. Folia Zool 53:215-226

Maitland PS (2000) Guide to freshwater fish of Britain and Europe. Hamlyn, London

Maitland PS (2004) Ireland's most threatened and rare freshwater fish: an international perspective on fish conservation. Biol Environ: Proc R Ir Acad 104B:5-16

Maitland PS, Lyle AA (2003) The distribution of lampreys in the River Teith. Forth Nat Hist 26:71-84

> Malmqvist B (1980) Habitat selection of larval brook lampreys (Lampetra planeri, Bloch) in a south Swedish stream. Oecologia 45:35-38

> Mateus CS, Almeida PR, Quintella BR, Alves MJ (2011a) MtDNA markers reveal the existence of allopatric evolutionary lineages in the threatened lampreys Lampetra fluviatilis (L.) and Lampetra planeri (Bloch) in the Iberian glacial refugium. Conserv Genet 12: 1061-1074

Mateus CS, Quintella BR, Rodríguez-Muñoz R, Almeida PR (2011b) Presence of the genus Lampetra in Asturias (northern Spain). Cybium 35:162-164

McPhail JD, Lindsey CC (1970) Freshwater fishes of northwestern Canada and Alaska. Fish Res Board Can Bull 173:1-381

Miñano S (1827a) Diccionario geográfico-estadístico de España y Portugal: dedicado al Rey Nuestro Señor. VI. Imprenta de Pierart-Peralta, Madrid

Miñano S (1827b) Diccionario geográfico-estadístico de España y Portugal: dedicado al Rey Nuestro Señor. VII. Imprenta de Pierart-Peralta, Madrid

> Morman RH, Cuddy DW, Rugen PC (1980) Factors influencing the distribution of the sea lamprey (Petromyzon marinus) in the Great Lakes. Can J Fish Aquat Sci 37: 1811-1826

Mrakovčić M, Buj I, Mustafić P, Ćaleta M, Zanella D (2007) Croatian red list: freshwater fish. Department of Zoology, Faculty of Science, University of Zagreb. Available at www.cro-nen.hr/crvena_lista.php (accessed on 15 November 2011)

Muséum National d'Histoire Naturelle (ed) (2003-2012) Inventaire national du patrimoine naturel. MNHN, Paris

O'Connell M, Wright JM (1997) Microsatellite DNA in fishes. Rev Fish Biol Fish 7:331-363

> Perea S, Garzón P, González JL, Almada VC, Pereira A, Doadrio I (2011) New distribution data on Spanish autochthonous species of freshwater fish. Graellsia 67: 91-102

Pérez-Bote JL (2002) Estatus y conservación de la ictiofauna en Extremadura. Rev Estud Extrem 58:303-312

Pérez-Bote JL, Roso R, Romero AJ, Perianes M, López MT (2005) Hallazgo reciente de la anguila Anguilla anguilla (Linnaeus, 1758) y de la lamprea marina Petromyzon marinus Linnaeus, 1758 en la cuenca extremeña del río Guadiana (suroeste de la Península Ibérica). Graellsia 61:135-137

Pérez Cebada D (2008) Historia de la contaminación minera en España-med. S. XIX-med. S. XXJ. Bol Geol Min 119: 383-398 
Philippart JC (2007) L'érosion de la biodiversité: les poissons. Rapport sur l'état de l'environnement wallon. Ministère de la Région wallonne. Direction Générale des Ressources Naturelles et de l'Environnement (DGRNE), Jambes

Potter IC, Hilliard RW, Bradley JS, McKay RJ (1986) The influence of environmental variables on the density of larval lampreys in different seasons. Oecologia 70: 433-440

Povž M (2011) Distribution and conservation status of the lampreys in Slovenia. Bull Lampetra VII:84-91

Prenda Marín J, Clavero Pineda M, Blanco Garrido F, Menor Campillo A, Hermoso López V (2006) Threats to the conservation of biotic integrity in Iberian fluvial ecosystems. Limnetica 25:377-388

Quintella BR (2006) Biology and conservation of the sea lamprey (Petromyzon marinus L.) in Portugal. PhD thesis, University of Lisbon

Quintella BR, Andrade NO, Almeida PR (2003) Distribution, larval stage duration and growth of the sea lamprey ammocoetes, Petromyzon marinus L., in a highly modified river basin. Ecol Freshw Fish 12:286-293

Quintella BR, Andrade NO, Dias NM, Almeida PR (2007) Laboratory assessment of sea lamprey larvae burrowing performance. Ecol Freshw Fish 16:177-182

Rašomavičius V (ed) (2007) Red data book of Lithuania. Ministry of Environmental Protection, Vilnius

Rassi P, Hyvärinen E, Juslén A, Mannerkoski I (eds) (2010) The 2010 red list of Finnish species. Ympäristöministeriö \& Suomen ympäristökeskus, Helsinki

Renaud CB (1997) Conservation status of Northern Hemisphere lampreys (Petromyzontidae). J Appl Ichthyol 13: 143-148

Rodríguez-Muñoz R (1992) Plan de conservación de la lamprea marina (Petromyzon marinus Linnaeus, 1758) en Asturias. Ecoplan, Oviedo

Rodríguez-Muñoz R (2000) Reproducción y desarrollo larvario en una población anadroma de lamprea marina (Petromyzon marinus L.). PhD thesis, University of Oviedo

Rodríguez-Muñoz R, Nicieza AG, Braña F (2001) Effects of temperature on developmental performance, survival and growth of sea lamprey embryos. J Fish Biol 58: 475-486

Rodríguez-Muñoz R, Waldman JR, Grunwald C, Roy NK, Wirgin I (2004) Absence of shared mitochondrial DNA haplotypes between sea lamprey from North American and Spanish rivers. J Fish Biol 64:783-787

Russian Academy of Sciences (2001) Red data book of the

Editorial responsibility: Steven Cooke,

Ottawa, Ontario, Canada
Russian Federation (animals). Ministry of Natural Resources of the Russian Federation, Moscow

Saat T, Jarvekulg R, Eschbaum R, Tambets J (2002) The status of threatened freshwater fishes in Estonia. In: Collares-Pereira MJ, Coelho MM, Cowx IG (eds) Freshwater fish conservation: options for the future. Fishing News Books, Blackwell Science, Oxford, p 34-44

Santo M (2005) Dispositivos de passagens para peixes em Portugal. Direcção-Geral dos Recursos Florestais, Lisbon

Santos JM, Ferreira MT, Godinho FN, Bochechas J (2002) Performance of fish lift recently built at the Touvedo Dam on the Lima River, Portugal. J Appl Ichthyol 18:118-123

Schreiber A, Engelhorn R (1998) Population genetics of a cyclostome species pair, river lamprey (Lampetra fluviatilis L.) and brook lamprey (Lampetra planeri Bloch). J Zool Syst Evol Res 36:85-99

Steindachner F (1866) Ichthyologischer Bericht über eine nach Spanien und Portugal unternommene Reise. III. Über die Fische des Tajo, Duero, Miño, deren Nebenflüssen und aus dem Jucar bei Cuenca. Sitzungsber Kaiserl Akad Wiss Wien 54:6-27

> Sugiyama H, Goto A (2002) Habitat selection by larvae of a fluvial lamprey, Lethenteron reissneri, in a small stream and an experimental aquarium. Ichthyol Res 49:62-68

$>$ Taberlet P, Fumagalli L, Wust-Saucy AG, Cosson JF (1998) Comparative phylogeography and postglacial colonization routes in Europe. Mol Ecol 7:453-464

> Thiel R, Winkler HM, Riel P, Neumann R and others (2009) Endangered anadromous lampreys in the southern Baltic Sea: spatial distribution, long-term trend, population status. Endang Species Res 8:233-247

Torrente JP (1999) Osos y otras fieras en el pasado de Asturias (1700-1860). Fundación Oso de Asturias, Oviedo

Urho L, Lehtonen H (2008) Fish species in Finland. Report 1B/2008. Finnish Game and Fisheries Research Institute, Helsinki

> Vladykov VD, Kott E (1979) Satellite species among the holarctic lampreys (Petromyzonidae). Can J Zool 57: 860-870

- Waterstraat A, Krappe M (1998) Distribution and abundance of Lampetra planeri populations in the Peene drainage (NE Germany) in relation to isolation and habitat conditions. Ital J Zool 65:137-143

Witkowski ZJ, Król W, Solarz W (eds) (2003) Carpathian list of endangered species. WWF and Institute of Nature Conservation, Polish Academy of Sciences, ViennaKrakow

> Zanandrea G (1959) Speciation among lampreys. Nature 184:380

Submitted: September 29, 2011; Accepted: December 4, 2011 Proofs received from author(s): January 23, 2012 